\title{
Effects of denervation on the expression of lactate dehydrogenase isozymes in the masseter muscle of developing mice
}

\author{
Norihiko Maeda ${ }^{1}$, Yoshitaka Suzuki ${ }^{2}$, Setsuko Suemune ${ }^{1}$, Nobuhiko Okada ${ }^{1}$, Yuji Yoshiko ${ }^{1}$ and \\ YASUMASA AKAGAWA ${ }^{2}$ \\ ${ }^{1}$ First Department of Oral Anatomy and ${ }^{2}$ Department of Removable Prosthodontics, Hiroshima University School of Dentistry, \\ Hiroshima University, Hiroshima 734, Japan
}

\begin{abstract}
The effects of the denervation of the masseter nerve on the isozyme pattern of lactate dehydrogenase (LDH) were investigated in the masseter muscle. We could not detect any significant changes in the relative level of each isozyme between the denervated masseter muscle and the contralateral muscle in male mice, although the treated muscle became severely atrophied. Sexual dimorphism in the LDH isozyme patterns existed even between the treated mice and intact female mice. The results indicate that the denervation of skeletal muscle never inhibits the appearance of sexual dimorphism in a biochemical property related to the energy supply to the muscle.
\end{abstract}

We found recently the existence of sexual dimorphism in the patterns of lactate dehydrogenase $(\mathrm{LDH})$ isozyme between masseter muscles of adult male and female mice (15). Maeda et al. (10) reported sexual dimorphism also in the number of trigeminal motoneurons that innervate the mouse masseter muscle, and they showed that expression of the LDH isozymes in the masseter muscle of the mouse was controlled by androgenic hormones (11). In the present study, we examined whether appearance of the sexual dimorphism is affected by the denervation in the masseter muscle of mice in which we found the sex-related difference in motor neurons innervating the muscle (10), in view of the Dubowitz's confirmation (3) that the appearance of different histochemical, physiological and biochemical properties of different types of muscle fibers was controlled by the nature of the innervation.

Male and female ICR mice were used throughout the present study. Pregnant females were kept in separate cages under alternating 12 -h periods of light and darkness. Newborn mice were kept with their mothers. Litters were reduced to ten pups on day 5 after birth. Unilateral denervation of the masseter nerve in male mice was performed on day 40 after birth. Unilateral sham-operation was also per- formed in the 40-day-old mice. Animals were sacrificed under deep anesthesia on day 60 after birth, and bilateral masseter muscles were removed. Then, body weights and wet weights of masseter muscles were determined. Morevoer, we also examined masseter muscles from intact osteopetrotic (B6C3Fe-a/a-op/op) mice in which masticatory motoneurons that innervate the masseter muscle were significantly reduced in number (16).

The masseter muscles were washed by stirring for $5 \mathrm{~min}$ in cold phosphate-buffered saline (PBS) and then cut into small pieces in $3 \mathrm{ml}$ of cold PBS. Each tissue was homogenized in a glass-Teflon homogenizer after treatment with a micro-homogenizer (model 23; Virtis, Gardiner, New York). The homogenate was centrifuged at $9,000 \mathrm{~g}$ for $30 \mathrm{~min}$ at $5^{\circ} \mathrm{C}$, and the resulting supernatant was used for electrophoretic separation of LDH isozyme. Horizontal agarose gels $(97 \times 110 \times 0.7$ $\mathrm{mm}$ ) fixed to a thin plastic plate (JOOKOO GP-109; JOOKOO, Tokyo, Japan) were used for electrophoresis. Each sample was subjected to electrophoresis at $10^{\circ} \mathrm{C}$ for $60 \mathrm{~min}$ by application of $3.09 \mathrm{~mA}$ per $\mathrm{cm}$ of membrane width after addition of $1 \mu \mathrm{l}$ of the following mixture: $80 \mu 1$ of $0.5 \mathrm{M}$ Tris$\mathrm{HCl}$ buffer (pH 7.2) and $20 \mu 1$ of $50 \%$ glycerin per $100 \mu \mathrm{l}$ of the supernatant. The gels were stained 

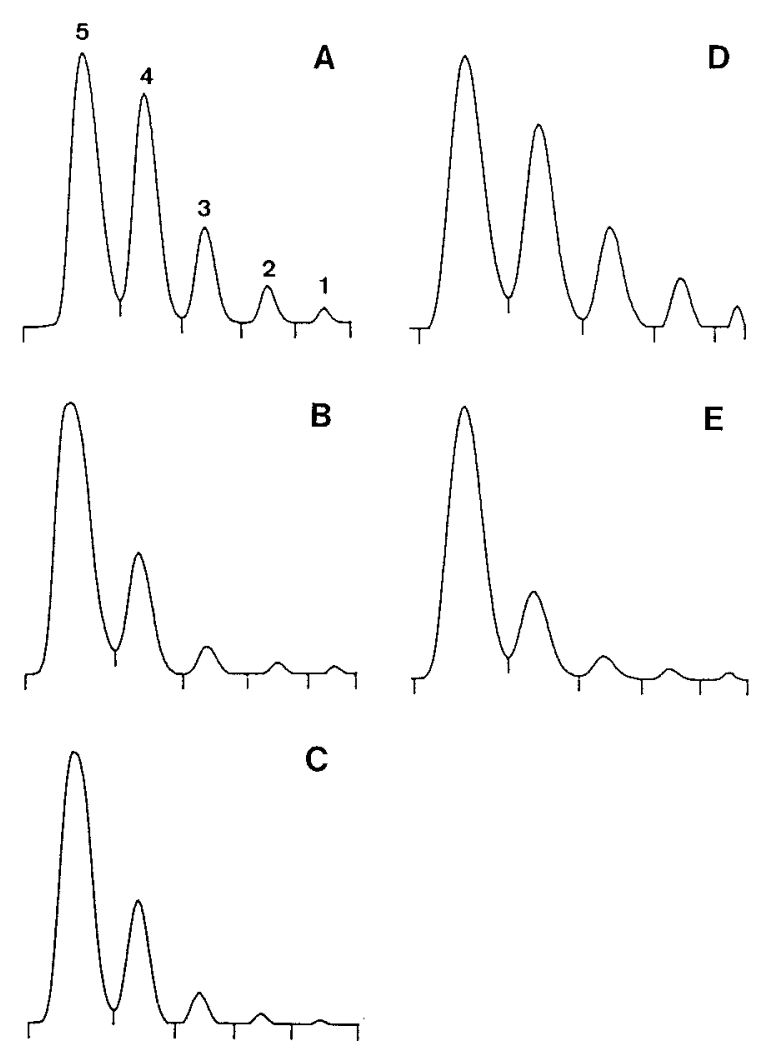

Fig. 1 Densitometric evaluation of lactate dehydrogenase isozymes in the masseter muscle. A, intact female; $\mathrm{B}$, male, denervated side; $\mathrm{C}$, male, contralateral side; $\mathrm{D}$, female op/op; E, male op/op; 1, LDH 1; 2, LDH 2;3, LDH 3; 4, LDH 4; 5, LDH 5

with the following reaction mixture: $1 \mathrm{ml}$ of Tristricine buffer ( $\mathrm{pH} \mathrm{8.6)}, 33 \mathrm{mg}$ of DL-lithium lactate, $9 \mathrm{mg}$ of NAD, $21 \mathrm{U}$ of diaphorase, and $1.2 \mathrm{mg}$ of nitro blue tetrazolium (NBT). The staining was performed at $37^{\circ} \mathrm{C}$ for $30 \mathrm{~min}$ in the darkness. The gels were fixed, washed with tap water and then dried. The zymograms were scanned with a densitometer (Densitron CR-20; JOOKOO). All data were analyzed by Student's $t$-test.

Fig. 1 shows the densitometric evaluations of $\mathrm{LDH}$ isozymes in the masseter muscle. We observed sex-related differences in the distribution patterns of LDH isozymes between masseter muscles from operated and sham-operated male mice and those of the intact female (Fig. 1, A, B and $\mathrm{C}$ ). There was also sex-related difference between male and female op/op mice (Fig. 1, D and E). There was no significant difference in the body weight between 60-day-old operated and shamoperated mice, whereas the body weight and the ratio of masseter muscle weight to the body weight decreased significantly in the operated mice (Table 1). As shown in Table 2, we detected sexual dimorphism in the distribution patterns of $\mathrm{LDH}$ isozymes in the masseter muscles between the operated and sham-operated males and the intact females; relative level of the LDH 5 isozyme was significantly higher in every masseter muscle from the treated male mice than that from the female mice, and relative levels of $\mathrm{LDH} 4, \mathrm{LDH} 3$ and LDH 2 isozymes were significantly higher in the masseter muscle from the female mice than the respective levels from the male mice. The distribution patterns of LDH isozymes in the denervated and sham-operated sides of the masseter muscles were not significantly different from those of the isozymes in the muscles on the contralateral side (Table 2). No differences were detectable in the distribution patterns of LDH isozymes in the masseter muscles from the operated mice, as compared with those from the sham-operated mice (Table 2).

In the present study, we examined in the masseter muscle, where sexual dimorphism in the distribution patterns of LDH isozymes had been detected (15), whether denervation affects the expression of LDH isozymes in the skeletal muscle of developing mice. We found that denervation had no effects on the LDH isozyme patterns.

Since the Bajusz's first observation that the 'red' muscle fibers of denervated rat and mouse triceps surae muscle atrophied more conspicuously than 'white' muscle fibers (1), there have been many reports of severe atrophy after denervation in type II fibers, which are ATPase-positive when examined after preincubation in alkali $(4,5,7,8$, $12,14)$. In contrast, findings related to the behaviour after denervation of type I fibers, which are ATPase-negative, are very different. Niederle and Mayr (13) reported that all types of muscle fibers in the extensor digitorum longus muscle were highly atrophied on the 120th day after denervation of the peroneal nerve, while the type I fibers in this muscle did not show any evidence of atrophy up to 42 days after denervation. Moreover, Riley and Allin (14) found histochemical changes in skeletal muscle fibers after denervation. Dubowitz (3) confirmed that the appearance of various histochemical, physiological and biochemical properties in different types of muscle fibers was controlled by the nature of the innervations.

On the other hand, Dawson et al. (2) and Kaplan (6) reported that the dominant LDH isozymes differed in each type of muscle fibers; slow-twitch-oxidative muscle fibers (type I fibers) are rich in the 
Table 1 Effects of the Denervation of the Masseter Nerve on the Ratio of the Weight of the Masseter Muscle to the Body Weight in 60-Day-Old Male Mice

\begin{tabular}{lccc}
\hline $\begin{array}{l}\text { Animals and } \\
\text { treatments }\end{array}$ & $\begin{array}{c}\text { Body weight } \\
(\mathrm{g})\end{array}$ & $\begin{array}{c}\text { Masseter muscle } \\
(\mathrm{mg})\end{array}$ & $\begin{array}{c}\text { Masseter muscle/body weight } \\
(\mathrm{mg} / \mathrm{g} \text { body weight })\end{array}$ \\
\hline $\begin{array}{l}\text { Operated mice } \\
\text { Denervated side }\end{array}$ & $39.4 \pm 1.3$ & & $2.0 \pm 0.2^{*}$ \\
Contralateral side & & $79 \pm 9^{*}$ & $3.6 \pm 0.3$ \\
Sham-operated mice & $37.9 \pm 1.9$ & $142 \pm 15$ & $3.5 \pm 0.2$ \\
Sham-operated side & & $134 \pm 4$ & $3.5 \pm 0.2$ \\
Contralateral side & & $132 \pm 12$ & \\
\hline
\end{tabular}

Denervation and sham-operation of the masseter nerve were performed unilaterally on the 40 th postnatal day. Each value is mean \pm SD from 6 animals. ${ }^{*} P<0.001$ vs the contralateral non-denervated masseter muscle

Table 2 Effects of the Denervation of the Masseter Nerve on Relative Levels of LDH Isozymes in the Masseter Muscle in 60-Day-Old Male Mice

\begin{tabular}{llllll}
\hline \multirow{2}{*}{$\begin{array}{c}\text { Animals and } \\
\text { treatments }\end{array}$} & LDH 5 & LDH 4 & LDH 3 & LDH 2 & LDH 1 \\
\cline { 2 - 6 } & & & & & \\
\hline Operated mice & & & & \\
$\quad$ Denervated side & $67.9 \pm 3.3^{* \#}$ & $26.8 \pm 2.2^{\#}$ & $5.7 \pm 1.1^{\#}$ & $1.2 \pm 0.5^{\#}$ & $0.3 \pm 0.2^{\#}$ \\
$\quad \begin{array}{l}\text { Contralateral side } \\
\text { Sham-operated mice }\end{array}$ & $67.8 \pm 5.3^{*}$ & $24.8 \pm 2.9$ & $5.3 \pm 1.8$ & $1.4 \pm 0.6$ & $0.6 \pm 0.2$ \\
$\quad$ & & & & \\
$\quad \begin{array}{l}\text { Sham-operated side } \\
\text { Contralateral side }\end{array}$ & $65.2 \pm 2.2^{* \#}$ & $27.6 \pm 1.5^{\#}$ & $5.3 \pm 0.7^{\#}$ & $1.1 \pm 0.4^{\#}$ & $0.3 \pm 0.1^{\#}$ \\
$\begin{array}{l}\text { Intact 60-day-old } \\
\text { female mice }\end{array}$ & $25.1 \pm 1.3$ & $4.8 \pm 0.5$ & $1.3 \pm 0.4$ & $0.5 \pm 0.2$ \\
\hline
\end{tabular}

Denervation of the masseter nerve and sham-operation were performed unilaterally on the 40 th postnatal day. Each value is mean \pm SD from 6 animals. ${ }^{*} P<0.001$ vs intact 60 -dayold females; ${ }^{* *} P<0.001$ and ${ }^{* * *} 0.05$ vs operated and sham-operated mice; "not significantly different from the contralateral side

LDH 1 isozymes, whereas fast-twitch-glycolytic fibers (type II B) are rich in the LDH5 isozyme. Sekino et al. (15) showed the sexual dimorphism in the distribution patterns of LDH isozymes between adult male and female mice. In addition, we recently found sex-related differences in the number of masticatory motoneurons that innervate the masseter muscle (10).

These observations suggest that the appearance of the sexual dimorphism in the distribution pattern of $\mathrm{LDH}$ isozymes in the masseter muscle is induced not only by sex differences in the nature of innervation, but also by the different levels of endogenous androgenic hormones between the two sexes. Nevertheless, we could not detect any effects of denervation of the masseter nerve on the LDH isozyme patterns in the masseter muscles that had atrophied after denervation; also, the male type of distribution pattern of LDH isozymes was seen even in the op/op mice, in which the number of the masticatory motoneurons innervating the masseter muscle is significantly reduced (16).

We have recently reported that some androgenic hormones and androgen receptors are involved in the appearance of sexual dimorphism of the distribution pattern of LDH isozymes; a short-term deprivation of androgenic hormones by testectomy prevented the appearance of male type of LDH isozyme pattern in the treated mice (11). We have also confirmed immunohistochemically that androgen receptors appeared in the masseter muscle before the sexual maturation of mice (9). Thus, it is strongly suggested that the expression of LDH isozymes in the masseter muscle of developing mice is 
mainly dependent on the androgenic hormones, but not on the innervation. However, we do not know the reason why the distribution pattern of LDH isozymes did not change in the denervated masseter muscle, despite its significant atrophy after denervation. The significance of the reduction in the number of masticatory motoneurons in the op/op mouse (16) also remains to be elucidated.

This work was supported in part by a grant from the Ministry of Education, Science and Culture of Japan (No. 05454489).

Received 20 May 1994; and accepted 22 June 1994

\section{REFERENCES}

1. BAJusz E. (1964) "Red" skeletal muscle fibers: Relative independence of neural control. Science 145, 938-939

2. Dawson D. M., Goodfriend T. L. and Kaplan N. O. (1964) Lactic dehydrogenases: Functions of the two types. Science 143, 929-933

3. Dubowitz V. (1967) Cross-innervated mammalian skeletal muscle: Histochemical, physiological and biochemical observations. J. Physiol. 193, 481-496

4. Guth L., Dempsey P. J. and Cooper T. H. (1971) Maintenance of neurotrophically regulated proteins in denervated skeletal and cardiac muscle. Exp. Neurol. 32, 478-488

5. Hikida R. S. and Bock W. J. (1976) Analysis of fiber types in the pigeon's metapatagialis muscle. II. Effects of denervation. Tissue Cell 8, 259-276

6. KAPLAN N. O. (1964) Lactate dehydrogenase-structure and function. Brookhaven Symp. Biol. 17, 131-153

7. Karpati G. and Engel W. K. (1968a) Histochemical investigation of fiber type ratios with myofibrillar ATPase reaction in normal and denervated skeletal muscles of guinea pig. Amer, J, Anat. 122, 145-155

8. Karpati G. and Engel W. K. (1968b) Correlative histochemical study of skeletal muscle after suprasegmental denervation, peripheral nerve section, and skeletal fixation. Neurology 18, 681-692

9. Maeda N., Ogata K., Hosoi M., Sato S., Maruyama S. and OKAмоTo H. (1994) Postnatal changes in the intensity of immunohistochemical reaction to androgen receptor antibody in mouse masseter muscle. Biomedical Res. 15, 89-93

10. Maeda N., Sugiyama H., Suemune S., Wakisaka H., Niida S., Ogata K. and Miyata K. (1993) Sexual dimorphism in the trigeminal motor neurons innervating the mouse masseter muscle. Brain Res. 627, 177-180

11. Maeda N., Suzuki Y., MiYata K., Wakisaka H., Nifda S, SuEmune S. and OKada N. (1993) Effects of androgenic hormones on the expression of isozymes of lactate dehydrogenase in the masseter muscle and tongue of mice. Biomedical Res. 14, 233-241

12. Mekichana G. and Gutmann E. (1974) Stimulation and immobilisation effects on contractile of denervated muscle. Pflügers Arch. 352, 165-178

13. Niederle B. and MaYr R. (1978) Course of denervation atrophy in type I and type II fibers of rat extensor digitorum longus muscle. Anat. Embryol. 153, 9-21

14. Riley D. A. and Allin E. F. (1973) The effects of inactivity, programmed stimulation, and denervation on the histochemistry of skeletal muscle fiber types. Exp. Neurol. 40, 391-413

15. Sekino K., Suzuki Y., Miyata K., Osawa K., Suemune S., Hosol M., NiIda S., Wakisaka H. and Maeda N. (1993) Sexual dimorphism of isozyme patterns of lactate dehydrogenase and effects of testectomy and ovariectomy on the isozyme distribution in the masseter muscle and tongue of mice. Biomedical Res. 14, 49-53

16. Suemune S., Kawata T. and Maeda N. (1994) Reduction of masticatory motoneurons in the trigeminal motor nucleus of the toothless (op/op) mouse. Biomedical Res. 15, 45-49 